
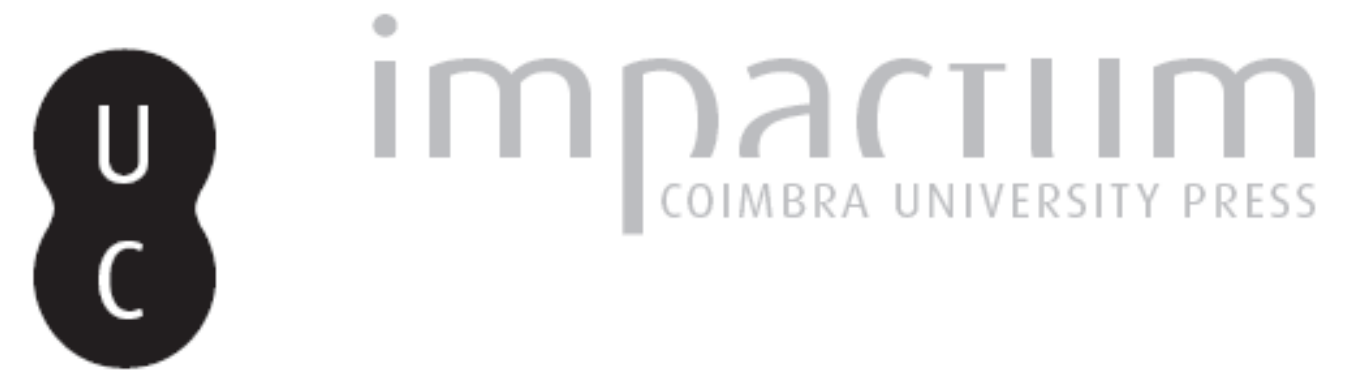

\title{
A situação feminina em Portugal na segunda metade do século XVIII
}

Autor(es): $\quad$ Silva, José Gentil da

Publicado por: Imprensa da Universidade de Coimbra

URL persistente:

URI:http://hdl.handle.net/10316.2/43863

DOI:

DOI:https://doi.org/10.14195/2183-8925_4-1_7

Accessed : $\quad$ 26-Apr-2023 11:07:48

A navegação consulta e descarregamento dos títulos inseridos nas Bibliotecas Digitais UC Digitalis, UC Pombalina e UC Impactum, pressupõem a aceitação plena e sem reservas dos Termos e Condições de Uso destas Bibliotecas Digitais, disponíveis em https://digitalis.uc.pt/pt-pt/termos.

Conforme exposto nos referidos Termos e Condições de Uso, o descarregamento de títulos de acesso restrito requer uma licença válida de autorização devendo o utilizador aceder ao(s) documento(s) a partir de um endereço de IP da instituição detentora da supramencionada licença.

Ao utilizador é apenas permitido o descarregamento para uso pessoal, pelo que o emprego do(s) título(s) descarregado(s) para outro fim, designadamente comercial, carece de autorização do respetivo autor ou editor da obra.

Na medida em que todas as obras da UC Digitalis se encontram protegidas pelo Código do Direito de Autor e Direitos Conexos e demais legislação aplicável, toda a cópia, parcial ou total, deste documento, nos casos em que é legalmente admitida, deverá conter ou fazer-se acompanhar por este aviso.

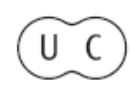




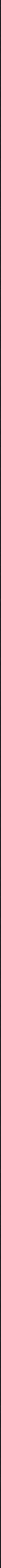




\section{A SITUAÇÃO FEMININA EM PORTUGAL NA SEGUNDA METADE DO SÉCULO XVIII}

\section{Introdução}

Em Portugal, a segunda metade do século XVIII viu uma reacção que com mais ou menos coerência procurou orientar o país de maneira a lhe dar um melhor lugar no concerto das Nações. Dela ficou como expoente o Secretário de Estado de D. José, até porque após o seu afastamento do po der a letargia de novo dominou apesar das iniciativas meritórias. $O$ interesse que merece a participação da mulher na vida social, económica e política, justifica que se procure saber como nesse meio século viveram e agiram as portuguesas, como eram vistas e apreciadas.

Porém desde o princípio devemos sublinhar quanto importa essa participação em geral desprezada. Vivemos numa civilização misógina que, ajudada pelo Renascimento e pela escolha feita dos textos clássicos, sofreu depois a terrível influência do mundo burguês, embora menos em Portugal que noutros países do continente europeu. Todavia, a separação e a oposição de homens e mulheres foi aqui também uma constante preocupação das elites.

Começaremos aqui por recordar aspectos significativos do lugar então reservado às mulheres e da sua situação perante o vasto e longo processo misógino acelerado no século XVI. Veremos depois qual era então a intervenção feminina na produção. Terminaremos acentuando como essa de Nice.

* Faculdade de Letras e Ciências Humanas da Universidade 
situação se degradava em Portugal também, embora menos aqui, como dissemos.

Decerto nestas poucas páginas indicaremos impressões de leitura mais do que daremos resultados de investigações pouco avançadas a propósito da mulher portuguesa; mas tais impressões entram na perspectiva da história geral de Portugal, compreendendo não só a dos homens mas também a das mulheres.

\section{A portuguesa, razão de escândalo}

A especificidade feminina, essa superestrutura lentamente elaborada a partir do Renascimento com a ajuda dos bons autores clássicos convenientemente escolhidos, é um dos elementos da separação de homens e mulheres, artificial mas útil para as estruturas políticas e sociais dominantes na Europa moderna. Assim, torna-se sujeito de escândalo. A portuguesa agrava o seu caso por não obedecer perfeitamente à regra europeia, civilizada.

Da boa e decerto alegre, gostosa, liberdade que fora a dos portugueses até ao século XIV pelo menos, encontram-se sólidos vestígios depois e ainda no século XIX. Não se trata aqui de tentar medir a importância no século XVIII, nem do adultério nem da mancebia. Pareceria à primeira vista que desde o século XVII pouco mudaram os casos de escândalo, quer dizer de mancebia denunciada em que só aparecem raros exemplos de incesto. A documentação de que dispomos deixa-nos naturalmente na ignorância do fervor maior ou menor com que se exprimem as testemunhas quando solicitadas, em particular os aldeões do Minho. Por vezes é simplesmente a garridice feminina que se denuncia, a propósito da imodéstia de mulheres solteiras que na igreja "se antepõem às casadas, fazendo seus acenos, estando inquietas» $\left.{ }^{(}\right)$.

Reconhecendo a «igualdade que se encontra nos defeitos de ambos os sexos", tal ou tal autor, por exemplo o cavaleiro

(') Segundo o interessante estudo de A. Franquelim S. Neiva Soares, «A sociedade do Antigo Regime nas visitaçôes e inquéritos paroquiais do Distrito de Braga», I, 1. Abação (S. Cristóvão), Revista Theológica, 1978, vol. XIII, p. 493 (1522, 1731, 1732); 540 (1715); 547-50 (1749); 530-32 (1692); 552-3 (1761). 
de Oliveira, faz apelo da imparcialidade $\left({ }^{2}\right)$. Isto será provado e em excesso, ao mais alto nível, porque a rainha $\mathrm{D}$. Maria terá conseguido ter um marido ainda menos interessante do que ela. Admitamos porém que haja essa igualdade até quando a «inocência do estado em que se logrão (os prazeres) aparta de si o temor dos escrúpulos e dos remorsos que se seguem em outros casos» $\left({ }^{3}\right)$. Esses outros casos são variados: por exemplo no doce Minho, tal viúva prenhe de homem solteiro que é soldado, mulheres amancebadas, algumas com a cumplicidade de parentes bondosos, do marido mesmo, o que sempre contrariara as autoridades e fizera gente ser degredada, no Brasil ou em Africa. Das visitas ao outro, alguns esposos "recebiam vacalhao, sardinhas e linho que o dito complice lhe dá... e lhe dá dinheiro, cordõis de ouro e vestidos, por o dito complice ser brasileiro" $\left.{ }^{1}\right)$. Em geral era mal visto que o amante desse prendas àquela que queria, vá-se lá saber porquê. Sente-se aqui a inveja, o amargor da injustiça, de quem vê satisfazerem-se assim interesses mútuos, mas na significação vasta desta palavra interesse, diríamos que no sentido nobre, por exemplo a propósito daquela Joana solteira criada de Francisco Alvares que em São Miguel das Caldas foi condenada por concubinato incestuoso com o amo. Não é depravação nem luxo; a maior parte desses amorosos é condenada a pequenas multas porque eles são pobres $\left({ }^{1}\right)$.

Bem pouco era comparado aos festins nos conventos do tempo del rei D. João V. Antes do casamento, todos os homens se usavam e gastavam o que tinham e não tinham $\left({ }^{4}\right)$. Tratava-se de ligações que exigia o sentimento, tão ausente da sociedade portuguesa, ou que pedia a fisiologia, individualmente, e que as romarias permitiam resolver por atacado $\left.{ }^{8}\right)$. Sempre e em toda a parte assim fora; a alegria de que gozavam as meninas lisboetas durante a semana santa era anual. Da Turquia contavam viajantes que em cada semana as mulheres, à sexta-feira, aproveitavam-se da ida para o banho para no caminho utilizarem anonimamente os homens que en-

( ${ }^{1}$ Vide nota na pág. anterior.

( $\left.{ }^{2}\right)$ Cavaleiro de Oliveira, Cartas, ed. Aquilino Ribeiro, Lisboa, 1960 , p. $50-1$.

(3) Ibid., p. 59.

(') Segundo Marquis de Bombelles, Journal d'un ambassadeur de France au Portugal, 1786-1788, Paris, PUF, Publ. du Centre Culturel Portugais, 1979, p. 47 e 301.

$\left.{ }^{5}\right)$ Cavaleiro de Oliveira, Recreação periódica, ed. Aquilino Ribeiro, Lisboa, Bibl. Nacional, 1922, II, p. 223. 
contravam e que consentiam $\left({ }^{8}\right)$. No Ocidente dizia-se que o anti-cristo nasceria de freira fecundada por frade; talvez por serem demasiados nenhum se distinga. "Pelo que toca às freiras de Lisboa, escreve soberbamente o cavaleiro de Oliveira, é melhor falar com elas do que falar nelas" $\left({ }^{7}\right)$. Frades, havia muitos e diziarse que a corte de Roma recebia de Portugal inúmeros pedidos de secularização ${ }^{8}$ ). Já D. Francisco Manuel de Melo glosara esses temas.

Mas ao fim e ao cabo, as acusações de devassidão lançadas contra os sacerdotes escondem que só estes conheciam a miséria sexual a que o casamento condenava as mulheres e que mais tarde descobrirão os médicos. Quando começou o seu reinado, D. Maria, talvez por ser mulher, recebeu inúmeros memoriais que denunciavam cruamente maridos e também de maridos que acusavam esposas $\left(^{\circ}\right)$. A realidade é verdadeiramente crua e a cada um convém fazer como puder. Decerto são mil as ocasiões de encontro. $O$ sismo aumentara-as mesmo e as barracas 'ou casas de madeira em que quase todos viviam, a confusão, tudo criara «uma ilícita e reprovada comissão de pessoas de diferentes famílias e sexos dentro nas mesmas barracas e na contiguidade e fácil ádito a elas, de que se tem seguido universal escândalo..." $\left({ }^{10}\right)$ Que se passaria na verdade? Provavelmente voltara-se à tradição do casamento não religioso, ou da união livre. Amava-se. Dizia-se que no paço, onde também tudo era provisório, o Embaixador de Espanha não perdia uma oportunidade de se fazer notar $\left({ }^{11}\right)$.

Assim, o que se diz dos santuários onde se marcam encontros às damas $\left({ }^{12}\right)$, é apenas o resultado de que a vida social seja parcamente satisfatória para as mulheres, muitas das quais têm uma vida activa. Voltando ao espírito que fora o português até ao século XIV, o Marquês proibira pela Lei Novíssima de 26 de Setembro de 1769 todo o procedimento criminal pelo concubinato simples. Antes, baptizam-se em Lisboa

( $\left.{ }^{\circ}\right)$ Bombelles, p. 125. O viajante é Cristóbal de Villalón, Viaje de Turquia (1757), ed. Antonio G. Solalinde, Madrid, 1942, p. 263.

p. 241-2.

${ }^{(7)}$ Cav. $^{\circ}$ Oliveira, Cartas, p. 82; Recreação periódica, II,

(8) Segundo Bombelles, p. 109, 301.

( ) Cav. Oliveira, Recreação periódica, II, p. 50-1. Cf. Bombelles, p. 304.

${ }^{\left({ }^{10}\right)}$ Em Eduardo Freire de Oliveira, Elementos para a história ao Município de Lisboa..., XVI, p. 478 (decreto de 8 Outubro 1760).

(1) Isto é De Bombelles que o diz, que não gosta do outro, p. 39. O próprio Confessor persegue as «ninfas do Palácio», sem se esconder, segundo W. Beckford, Diário, p. 111.

(1) Cav. Oliveira, Recreação periódica, I. p. 25. 


\section{A situação feminina}

filhos ilegítimos em proporções assaz importantes, embora variáveis de uma paróquia à outra e que estão acima da norma citadina $\left({ }^{13}\right)$. Faltam em Portugal desses estudos sobre a fecundidade, mas, pelo pouco que sabemos, parece que no centro do país tais proporções eram inferiores $\left({ }^{14}\right)$. Tais comportamentos variam muito. Onde as escravas são numerosas contam-se mais desses baptismos, como de filhos de pais incógnitos; nas outras, a tendência parece ser que se trate de pai e mãe incógnitos $\left(^{15}\right)$. Porém a riqueza dos resultados de tais estudos exige que se espere deles uma mais ampla informação. De qualquer modo, ia-se generalizando o costume de recolher as crianças abandonadas e em 1783 reconhece-se oficialmente esta função da Roda, «lugar discreto» de que se esperava que evitasse os infanticídios $\left({ }^{16}\right)$. Decerto já no século XVI, «a ordenança dos enjeitados» recolhia em Lisboa, de 450 a 500 crianças anualmente $\left({ }^{17}\right)$.

Na Lisboa do século XVIII, os "meninos da Palhavã», privilegiados ou não entre a corte de bastardos de D. João V, eram uma espécie de instituição que exprimia pela sua presença a vanidade do casamento. Famílias antigas e ilustres aceitavam naturalmente dar uma filha a herdeiros de bastardias sucessivas. Separações frequentes dos esposos davam nasci mento a bastardos que não eram vergonha para ninguém $\left({ }^{18}\right)$. Alguns deles, Marialvas, Cadaval, disfrutavam de cargos elevados $\left({ }^{19}\right)$.

( $\left.{ }^{18}\right)$ Cf. por exemplo, M. de Lourdes Akola da Cunha Meira do Carmo da Silva Neto, A freguesia de Nossa Senhora das Mercês de Lisboa no $10^{\circ}$ quartel do século XVIII, Lisboa, 1967, p. 32, e Jacques Dupâquier, La population française aux XVII et XVIII' siècles, Paris, 1979 , p. 110 e segs. Ver, Classes dos crimes por ordem systematica..., por Joaquim José Caetano Yereıra e Sousa, Lisboa, 1816, p. 209.

${ }^{\left({ }^{4}\right)}$ Segundo por exemplo, Carlota Maria Gonçalves Borges Landeiro, $A$ vila de Penamacor no primeiro quartel do século XVIII, Lisboa, 1965.

${ }^{(15)}$ Ainda na freguesia das Mercês, comparada à de Santa $\mathrm{Ca}$ tarina, ibid., pp. 36-7.

${ }^{(16)}$ Lisboa, o Porto, mas também outras cidades, suportam pesados encargos, cf. E. F. Oliveira, Elementos, V, pp. 98-9. Sobre a mortalidade, em 1672 fala-se de 300 a 400 crianças enjeitadas que morrem todos os anos, VII, p. 369. O P. Agostinho Rebelo da Costa, Descrição... do Porto $(1788), 1945$, p. 134 , indica uma média anual de 902 expostos.

(17) Segundo Cristóvão Rodrigues de Oliveira, Sumário... de Lisboa (1551-1554), ed. Augusto Vieira da Silva, Lisboa, 1938, pp. 53-4.

(18) Apreciações de Bombelles, p. 47, 54, 56, 137, 178; e de Wiliam Beckford, Diário, ed. João Gaspar Simões, Lisboa, Empresa Nacional de Publicidade, 1957, p. 54, 56.

${ }^{\left({ }^{10}\right)}$ Bombelles, p. 299-300. 
O casal não parece ter muitos filhos, à volta de quatro talvez, em Lisboa como na província. Deve ser assim em geral porque mais tarde se ajudavam os que tinham mais de cinco $\left({ }^{20}\right)$. Ora a impressão dos estrangeiros era que os portugueses gostavam da vida de família. Com efeito, onde havia capelas a que se atribuía a faculdade de tornar os esposos férteis, os camponeses vinham dançar de esperança $\left({ }^{21}\right)$.

Uma sociedade desesperava de tédio, ao abandono, e reagia como podia. As meninas não saíam nem com a mãe. O Marquês quisera contrariar essa mania, dizia-se. Têm de estar casadas para se divertirem, como o fizera antes o senhor marido. Na medida do possivel, porque a verdade é que a prosápia de certas famílias lhes fazia preferir que as filhas morressem de fome a dá-las a homem rico mas plebeu $\left({ }^{22}\right)$.

Uma atitude de condescendência domina o que se faz e diz das mulheres, compensando como se pode as angústias masculinas. As exigências femininas, que alguns estrangeirados pretendem ser novidade, exprimem as insatisfações permanentes. Por isso são tão festejados o entrudo, os aniversários, o que houver, multiplicam-se visitas falsamente atribuídas à moda estrangeira e que já no século XVII denunciavam os tratadistas bem casamenteiros. Na linha do que no princípio do século XVI se escrevera, os estrangeiros estranhavam a presença de mestres de dança, de negras e negrinhas, de ciganas que lêem a sina ou levam bilhetes doces. Uma infinidade de bocas inúteis e de gente considerada perigosíssima para a tranquilidade do marido convivia com os frades convidados por ele mesmo. Tudo isso era o que sempre fora, o que se aceitava no Minho rural, não começara quando se separaram os esposos com a moda então dita nova de quarto separado e de criadagem própria para cada um, marido e mulher $\left({ }^{28}\right)$.

$\left({ }^{20}\right)$ Cf. José de Abreu Bacellar Chichorro, Memória económicopolítica da Província da Extremadura..., (1795) ed. Moses Bensabat Amzalak, Lisboa, 1943, p. 47 (1795) e Joel Serrão et al., «Subsídios para o estudo da demografia de Trás-os-Montes nos fins do século XVIII», Economia e finanças, 1973, vol. XLI, p. 6, 11, 18, assim como, por exemplo, Custódio José Gomes de Vilas-Boas, Geografia e economia da província do Minho nos fins do século XVIII, ed. António Cruz,, Porto, Fac. de Letras da Universidade do Porto, 1970 , p. 129 e segs.

${ }^{\left({ }^{21}\right)}$ Em De Bombelles, p. 49, 102. O infanticídio e o aborto eram punidos de morte pelas Ordenações, 1. I, tit. 73, § 4. 1.5. tit. 35. Classes äos crimes, pp. 309-313.

$\left.{ }^{(22}\right)$ Bombelles, p. 80, 198, 301.

$\left.{ }^{23}\right)$ Ibid., pp. 34, 49-50, 125; W. Beckford, p. 153. A coincidência não e fortuita com D. Francisco Manuel de Melo, Carta de guia de casados (1651), Lisboa, 1965, p. 50. 
Vivendo entre elas, as senhoras cercadas das suas criadas, das suas negras, da garotada de todas elas, distraem-se como podem e sabem. Frades estrangeirados tocam violino e bandolim ou esgrimem com jovens estrangeiros desses que servem no exército. Decerto a música se italianizara como pudera enfim, depois da viragem afro-crioula do século XVII; o que queriam meninas e damas era cantar, tocar, dançar, como sabiam e eram capazes. Acontecia por vezes que uma jovem brasileira surpreendesse pela justeza com que utilizava um instrumento musical, pelo rigor do seu gosto. De qualquer modo, as velhotas adoravam a música. Para todos se tratava de "matar o tempo». Que maçada, escreve em francês De Bombelles, o Embaixador de França. Tudo isto parece bem inocente $\left({ }^{24}\right)$. Os espectáculos públicos a que ia mesmo a rainha parecem-lhe muito mais indecentes, mais do que teriam pensado os prelados romanos no século do Renascimento $\left({ }^{25}\right)$. $\mathrm{Na}$ realidade, ninguém era enganado, fora o janota Beckford, o altaneiro De Bombelles; as mulheres portuguesas não eram tão inocentes como se possa ter pretendido, nem à rainha faltava espírito. Se a ela o marido não deixou senão boas recordações, isso terá sido por razões íntimas que os historiadores ignoram, naturalmente. Havia casado relativamente tarde, só aos 26 anos, com um tio de 46, "meu querido tio". Nos meios distintos que frequentavam embaixadores, as mulheres casavam muito mais cedo, algumas antes dos 12 anos $\left({ }^{28}\right)$. Isto prova a inanidade do costume (talvez recente, este, de quando data?) que impedia as meninas de saírem, ou explica que, seguindo sempre a opinião de D. Francisco Manuel de Melo, se pensasse que mais valia correr o risco de mulher jovem, mas inexperimentada. Quando o Conde de São Tiago que passara alegremente os 60 , decide casar-se, escolhe uma jovem que diz a seu pai, o Conde de Resende, que não poderia nunca tornar a ser tão infeliz como o fora na casa paterna $\left({ }^{27}\right)$. O Duque de Lafões casa aos 70 anos com uma Marialva de 15. Desta maneira, quem se importaria com o que escrevia um doutor Fernando José de Almeida, de resto perseguido pela Inquisição, que aconselhava casar entre 18 e 30 anos, e que cada um olhas-

\footnotetext{
(24) Bombelles, pp. 80, 100, 107, 137, 202, 208, 211-2, 243-4, 252.

${ }^{25}$ ) Bombelles, pp. 178-9. Cf. Fernando de Castro Pires de Lima, A mulher vestida de homem, Lisboa, 1958, p. 136.

$\left({ }^{2}\right)$ Bombelles, pp. 51, 80, 235.

(") Ibid., p. 240.
} 
se antes pelo seu estado de saúde, porque as moléstias passam dos pais aos filhos $\left({ }^{28}\right)$.

Sem ir tão longe, a Coroa promoveria mais tarde casamentos; por exemplo os "julgadores e oficiais de Justiça» tinham um ano a partir da entrada no serviço para constituir família e, se enviuvavam, deviam recasar no ano seguinte $\left({ }^{29}\right)$. Mais parece que se queria arrumá-los. Mas apontava-se o interesse que haveria em estabelecer fábricas em terras da província, para aumentar os lucros das trabalhadeiras, de maneira a facilitar-se-lhes o casamento $\left({ }^{30}\right)$. Porém pareceria que na realidade os casamentos de escravos já fossem menos frequentes. Ainda as escravas encontram marido livre, mas só excepcionalmente um homem escravo casa com senhora que o não seja $\left({ }^{31}\right)$.

Esse é provavelmente um dos sinais mais seguros da maneira como a sociedade portuguesa se fechava e se separavam os sexos desde o século XVI $\left({ }^{32}\right)$. Por outro lado, as cumplicidades perduram, dando-lhe esse aspecto que tanto chocava os estrangeiros e contrariava os estrangeirados. As senhoras da alta, seis semanas após o nascimento, confiavam os filhos a uma ama qualquer. Uma dessas que levavam os enjeitados e de preferência, mulher do campo. Só no século XIX os médicos discutiriam a propósito do leite, preferindo-se então o de vaca ao de cabra. Deve ser tomado directamente do seio ou, pelo menos, acabado de ordenhar, porque se encontra então dotado de uma espécie de vitalidade; as moléculas que o compõem em vista das suas afinidades de agregação e composição, permanecem ligadas e formam um líquido homogéneo $\left({ }^{38}\right)$.

Tolerantes, conciliantes ou simplesmente lúcidos, os portugueses gozam vendo as mulheres felizes, por exemplo à mesa. Sabe-se quanto gostam de comer, porém só se servem depois delas, do que deixaram, e isso choca o Embaixador fran-

$\left({ }^{28}\right)$ Em M. Ferreira de Mira, História da medicina portuguesa, Lisboa, 1948, p. 313.

$\left({ }^{20}\right)$ Segundo J. de Abreu Bacellar Chichorro, p. 47.

$\left({ }^{30}\right)$ Ibid., p. 57.

$\left.{ }^{(32}\right)$ Cf. M. de L. A. da C. M. do C. da S. Neto, A freguesia... das Mercês..., p. 81 e segs.

$\left.{ }^{(32}\right)$ No século XV descobrira-se que os africanos eram bons trabalhadores, bons esposos, bons pais; no século XVI, em Lisboa, ain Coimbra, un pouco por toda a parte, há casamentos mistos; gradualmente parecem diminuir como mostram trabalhos em curso na Universidade de Nice.

$\left({ }^{33}\right)$ Bombelles, p. 196; M. F. de Mira, pp. 312, 313, 314. Haviam-se feito observações na casa dos expostos. 
cês, obrigado a reconhecer, seja qual for a antipatia com que considera a Nação, que as mulheres são tratadas com respeito $\left(^{34}\right)$. Deixa-se-lhes dispor como se passará o sarau. Enquanto eles discorrem sobre a decadência do país depois que o marquês deixou o poder, as senhoras, muito mais numerosas, cansam-se de falar de modas e pedem que se toque música. A bonomia portuguesa reúne facilmente sessenta ou oir tenta pessoas para ouvir cantar a esposa, as sobrinhas, as primas, durante horas a fio $\left.{ }^{85}\right)$.

Em Portugal como noutros países, por exemplo em França, a viuvez é uma espécie de alforria. Descobre-se que são alegres e espirituosas $\left({ }^{36}\right)$. Havia felizmente desaparecido o triste costume de as enclausurar. Aquelas que tinham servido na Corte quando solteiras, podem então voltar. As que não tinham tido filhos deviam de facto deixar a casa do falecido. Só bem mais tarde, lá para o fim do século, se editam disposições legais favorecendo os recasamentos um ano após a viuvez $\left({ }^{37}\right)$. Seria um bem?

Muitas dessas mulheres sabem línguas, lêem, têm uma conversa agradável. $\mathrm{Na}$ maior parte dos casos naturalmente, como acontece com eles, compreende-se que se ridicularizam as "meninas que se prezam de doutas». Mas o frenesi desses escarnecimentos esconde mal o despeito com que se reconhecem as capacidades femininas numa sociedade que sobretudo nos meios letrados, estrangeirados, deve ser misógina como lá fora $\left({ }^{38}\right)$.

Mesmo das rainhas e princesas se fala menos do que merecem seus méritos: Maria Ana de Austria que foi regente e terá favorecido a ascensão de Pombal, esposo da sua compatriota; a princesa do Brasil depois rainha, D. Mariana Vitória,

$\left({ }^{34}\right)$ Bombelles, pp. 107, 136. No Norte, cobrem-nas de ouro, o que possuem as mulheres do campo excede o valor de trinta milhōes de cruzados, escreve o P. ${ }^{\circ}$ Agostinho Rebelo da Costa, p. 19. Há muito nas paróquias tripeiras da Sé, S. Nicolau e Santo Ildefonso, nas comarcas da Maia e Penafiel.

${ }^{\left({ }^{35}\right)}$ Bombelles, pp. 243-4.

( $\left.{ }^{36}\right)$ Ibid., p. 80, dá o exemplo de D. Inês da Câmara. Outros trabalhos em curso mostram que em Paris, são mulheres casadas cedo e depressa viúvas que criam salões, animam a vida cultural e produ$z \in m$ numerosas obras que o século XIX fez por esquecer. Em Lisboa, é o caso da viúva de Miguel Arriaga, cf. W. Beckford, Diário, p. 119.

${ }^{(37)}$ Bombelles, pp. 80, 181. Cf. J. de A. Bacellar Chichorro, Memória económica, cit., p. 48.

$\left.{ }^{(38}\right)$ Cf. O Anónimo. Journal portugais du XVIII• sièle (1752-1754), ed. Marie-Hélène Piwnik, Paris, Centro Cultural Português, 1979 , pp. 106-7. Mostra o comentário quanto o autor das adaptaçōes é estrangeirado, querendo corrigir os comportamentos nacionais. 
que a Corte de França não desvairara, culta e capaz; a 3. ${ }^{2}$ Marquesa de Távora, D. Leonor Tomásia, que reunia nos seus salões os inimigos do Marquês de Pombal e foi executada com seu marido e primo, três anos mais novo. Casara com 18 anos. $\mathrm{Na}$ nobreza, o Embaixador de França, homem difícil e pouco simpático para com as portuguesas, admira a Condessa de Vimieiro e, embora a deteste, é finalmente levado a reconhecer os talentos de Alcipe. A vida da Condessa d'Oyenhausen, nascida Alorna, não foi fácil. A longa prisão com a mãe, um marido endividado que vegeta longe da Corte de Viena onde é Embaixador e, talvez felizmente, da mulher, obrigam-na a manifestar-se hábil diplomata, forçada a fazer projectos sobre projectos, recebida com pouca ou nenhuma simpatia por homens que, quase todos, procuram prejudicá-la. Conquista pouco a pouco os comerciantes da colónia francesa de Lisboa, recitando versos que improvisava. D. Leonor de Almeida Portugal é notável pela coragem com que se bateu em condições desfavoráveis. Até Pina Manique a detestou, o pobre! Crêem fazer-lhe cumprimentos autores que falam da sua "varonilidade serena", mas também é verdade, "dum ânimo generoso e duma compreensão objectiva das circunstâncias"; ela ajudou Herculano e "como Madame de Stael... fazia voltar a atenção da mocidade para a arte da Alemanha, a qual veio dar seiva nova à arte meridional que vegetava na imitação servil das chamadas letras clássicas, e ainda estas estudadas no transunto infiel da literatura francesa da época de Luís XIV". Será difícil com efeito encontrar quem se lhe compare e, na verdade, quantos versos saberia de cor! ${ }^{89}$ ) E porém possível encontrar na província, uma mademoiselle Seixas que surpreende ouvintes pretenciosos, pelo seu talento musical e artístico que ninguém ajudara $\left({ }^{40}\right)$. Outras surpresas aguardam o estrangeiro.

\section{A força de trabalho feminina}

Se os senhores de fora e alguns da terra detestam Alcipe, decerto desprezavam as mulheres que trabalham. Com efeito, nem todas as portuguesas eram meninas Seixas prendadas como a filha do doutor das Caldas da Rainha. Por isso com-

$\left({ }^{39}\right)$ Bombelles, pp. 190, 211, 250, 287, 289, 299, 313, 366. Cf. Fidelino de Figueiredo, História da literatura clássica, 3. ${ }^{\mathrm{a}}$ época: 1756-1825, Lisboa, 1931 , p. 285 e segs.

${ }^{\left({ }^{10}\right)}$ Bombelles, p. 186. 
preende-se quanto o presumido William Beckford sofria de ver "o Duque de Cadaval e alguns jovens da primeira sociedade» dançarem com as modistas, costureiras e damas de companhia da cidade de Lisboa. São "gente que só se sente bem na companhia de pessoas ordinárias» ( $\left.{ }^{41}\right)$. Essas e outras que ajudam, quem sabe, a gastar pela luxúria os senhores fidalgos, fazem, pelo seu número mas também pela importância das suas actividades, que o trabalho feminino seja considerável em Lisboa e no país.

Nos meados do século XVI, mais de 9.000 mulheres $\mathrm{da}$ capital do reino eram descritas como trabalhadeiras; as numerosas alfaiatas (1.606) e lavrandeiras (1.173) testemunham certamente do gosto de se ataviar, enquanto as regateiras de porta (900) e da Ribeira (660), as padeiras (782), as peixeiras (400) e outras mais, asseguram o abastecimento quotidiano $\left(^{42}\right)$. Dois séculos mais tarde, essas são ainda actividades femininas nos mercados e pelas ruas.

$\mathrm{Na}$ Ribeira há contadeiras da sardinha; as esposas e viúvas dos pescadores vendem peixe, o que não é permitido a moças ou solteiras. Porém, a vendedeira enferma pode escolher quem a substitua, sua mãe, uma filha ou prima co-irmã que seja capaz ( $\left.{ }^{43}\right)$. $O$ negócio fica em família. Essas mulheres não eram muito numerosas e em 1771 reconhece-se que se viu demais na construção do novo mercado. Com efeito, "o número das vendedeiras do pescado na Ribeira de Lisboa não pode de nenhuma sorte encher os 256 lugares das 32 cabanas da mesma Ribeira", a nova, na praia de São Paulo. Resolve-se acomodar nas primeiras dessas cabanas, "colarejas que vendem fruta ao povo...» $\left({ }^{44}\right)$.

Também na Ribeira e no Rato, couveiras, medideiras, regateiras, casadas ou viúvas, vendem legumes. Outras ficaram na Praça do Rossio e Largo de São Domingos. E gente pobre. Uma couveira que trabalhou durante 40 anos, paga à cidade 750 réis de pensão anual, aluguer do lugar onde trabalha. Esperava-se que abolindo as taxas dos preços dos víveres, crescesse "o número das vivandeiras e com a concorrência pp. $92-4$

(11) W. Beckford, p. 108.

(अ) Segundo Cristóvão Rodrigues de Oliveira, Sumário..., XVII, p. 323.

("3) E. F. Oliveira, Elementos, XI, p. 572, nota; XIV, p. 227;

(“) Ibid., XVII, p. 304. 
delas, a abundância dos víveres, para se diminuir o preço deles em comum benefício do... povo" $\left({ }^{45}\right)$.

Outras mais pessoas vendem na Ribeira sem ter lugar certo, "maltezes e mulheres de soldados"; mulheres também vendem pelas ruas, o que ajuda as pessoas que não têm criados que as sirvam e estão esperando que essas mulheres venham "pelas portas vender o comestível». Não o podem fazer nem solteiras, nem pretas ou escravas, contra o que protesta a cidade, porque é bem «usarem de alguns tratos com que licitamente se sustentam e seus senhores e famílias». Bastará que «não excedam as taxas, não usem pesos diminuídos ou não aferidos e não delinquam». Muitas colarejas vendem de porta à porta caças, frangos e outros géneros. Lisboa é a graça dessas "revendonas» e dos pregões com que se anunciam, é a diligência com que servem a população. Ao necessário, junta-se o agradável, algumas vendem pão-de-ló $\left({ }^{48}\right)$.

Também «é preciso que haja padeiras que façam o pão e o vendam às tendeiras, para estas o tornarem a vender". As padeiras não querem ser confundidas com essas tendeiras. São mulheres casadas e viviam «de suas portas a dentro com grande recolhimento, conforme deviam ao seu estado, com seus filhos e filhas donzelas,... para com o limitado ganho que lhes ficava com o seu trabalho e de seus maridos, pobres oficiais, os poderem alimentar e governar...». Também as senhoras que fazem pão-de-ló querem ser reconhecidas por «mulheres recolhidas e honestas». "Comummente», como afirmam ( $\left.{ }^{47}\right)$.

O sentimento de classe de esposas de oficiais exprime-se no estilo untuoso e na referência à mediocridade, ao recolhimento caseiro e familiar que durou até ao tempo de Júlio César Machado e Eça de Queirós, e ressumava o tédio da mediocridade pequeno-burguesa. Na rua, diante das «escadas do Hospital do Rossio", o espectáculo é mais colorido. Pretas vendem milho, arroz e chícharos. Com elas estão os garotos. Chega um mariola e põe "de propósito os pés em a saia duma preta». Das palavras chega-se às bofetadas. $\mathrm{O}$ marido intervém. Querem prendê-las todas. Pagam anualmente um cruzado, cada uma, "e nesta posse estavam desde que o mundo era mun. do, por si e suas antepassadas» $\left.{ }^{48}\right)$.

Que boa consciência de direitos e feitos antigos. Essa Lisboa popular e industriosa, não sendo embora tão velha

("5) Ibid., XV, p. 75-6; XVI, pp. 414-5; XVII, pp. 10-11; sobre a abolição das taxas. XVII, pp. 24-5.

(18) Ibid., XI, p. 610; XIV, p. 221; XV, pp. 373-4; XVII, p. 328.

("7) Ibid., XI, p. 280; XIV, p. 224; e XV, p. 374, nota.

(4) Ibid., X, p. 330-2. 
como dizem, precisara sempre de alguém que pusesse ordem nessas discórdias e termo às injúrias entre as "mulheres que vendiam nas praças públicas, lavavam nos tanques de Alfama, e outras de análogas condições» ${ }^{49}$ ). A palavra colareja herdou a má nota merecida por algumas dessas bravas mulheres.

Havia um juízo, chamado "das brabas», que fazia expor no pelourinho as mulheres useiras de bradar, com um freio na boca, claro. Exerce esse juízo em 1765 uma mulher que lhes é pois superior e "age com impropriedade e em ódio das miseráveis que vendem e lavam...» $\mathrm{A}$ impropriedade está em que uma mulher «não é pessoa legítima para oficiar em causas de justiça», lembra a Câmara $\left(^{\left({ }^{\circ}\right)}\right.$. Na verdade, elas não são sequer testemunhas e isto desde a Idade Média $\left({ }^{81}\right)$.

Porém essas criaturas que, satisfazendo "o ventre da cidade", por vezes dizem demais o que lhes parece, são solicitadas por ocasião das festividades; por exemplo quando da aclamação de D. José, uma vendedeira de hortaliça, Maria Teresa de seu nome, fora mordoma da dança das mulheres couveiras e gastara $45 \$ 000$ réis. Também as regateiras de peixe e as medideiras do Terreiro se tinham exibido. As «festas de toiros» eram sempre acompanhadas de tais exibições. A inauguração da estátua equestre dera naturalmente lugar a festas. Se, dessas mulheres, mais gastou quem mais ganhava, vale a pena lembrar que as couveiras contribuíram com $119 \$ 180$ réis, as colarejas com $48 \$ 920$ e as peixeiras com $30 \$ 569$. As mulheres da Casa dos Vinte e Quatro gastaram $20 \$ 000$, segundo a conta apresentada por D. Maria Antónia, com certeza oficial do seu ofício. Tinham posto "prontas doze pessoas... vestidas para as danças... na praça do comércio" $\left.{ }^{(52}\right)$. Desta vez os companheiros «marialvas» de Mr. Beckford não terão tido maneira de as enlaçar... Quem sabe!

Para falar das alfaiatas e outras lavrandeiras, seria necessário dispor de documentos, como a literatura de cordel que tanto fala da clientela. A relação entre umas e outras aparece em filigrana em muitos escritos da época. Continua uma chusma de mulheres a vender linho e lençaria de porta a porta, como no tempo de D. Francisco Manuel de Melo, ou como ele o escreveu.

$\left({ }^{+0}\right)$ Ibid., XVII, pp. 19-20, 23.

(50) Ibid., id., pp. 19-20.

$\left({ }^{51}\right)$ Cf. A. F. Neiva Soares, p. 434. As condições do testemunho feminino, em Livro das leis e posturas, Lisboa, Faculdade de Direito, Universidade de Lisboa, 1971, p. 37. 515 (1775).

$\left.{ }^{(52}\right)$ E. F. Oliveira, Elementos, XVI, p. 126 (1755); XVII, p. 487, 
Quem mais escreve ou mais publica, os estrangeiros, esses iam espreitar o sapateiro que, nos jardins de Sintra, trabalhava com a mulher e o filho, ou verificar que estavam bem alinhadas as casinhas em que Pina Manique quisera alojar mulheres das «ilhas portuguesas» para as fazer trabalhar, sem sucesso $\left({ }^{63}\right)$. A esse respeito, havia que ver. Na Ribeira das Naus estabelecera-se uma casa de correcção "com o nome de casa do estopo onde se recolhiam e empregavam as mulheres de má vida, para ao mesmo tempo afugentar os espíritos malignos dos corpos das possessas. Havia muitas. Também por isso e para aumentar a população e a indústria no Algarve, Pina Manique fazia casarem-se órfãs dotadas. Toda essa boa gente vinha do estabelecimento que o intendente-geral da Polícia fundara e onde trabalhavam as crianças recolhidas. Outras fazem botões no Arsenal, para os uniformes, ou desenham ornamentos copiados de bons modelos $\left({ }^{54}\right)$.

Pelo país fora, não era o intendente, eram as necessidades da vida que obrigavam mulheres e raparigas a trabalharem desde cedo. No Porto, «assedam linho para as obras miúdas» da fábrica da Cordoaria Nova, outras ajudam a fazer "sedas, fitas e ligas». Ver mulheres trabalhar é habitual. No campo, "cavam, aram e fazem todo o trabalho da lavoura como os homens", havendo porém "diversos serviços do campo menos pesados... para que uma mulher ou um rapaz é mais ágil que o homem mais robusto». Paga-se-lhes menos $\left({ }^{55}\right)$. "Se não fossem os grandes ranchos de mulheres que descem (à baixa Extremadura) das terras da Beira e alta Extremadura nos meses d'outubro, novembro, dezembro, apenas se poderia apanhar uma terça parte da azeitona da sua lavra" $\left({ }^{86}\right)$. Em Trás-os-Montes, as tecedeiras e fiadeiras aldeãs de Mirandela e Moncorvo "não são mestras»; trabalham em sua casa. Espera-se com o novo método piemontês elaborar um novo regimento para as fiadeiras da seda. Entretanto, apesar da pre. caridade das condições de trabalho dessas mulheres, "o fisco leva-lhes grande quantidade de dinheiro" e "se vião obrigadas [a] desamparar os ofícios ou mudarem de terra" $\left({ }^{67}\right)$. A fiação de linhas, estopas e lãs, acompanha-se do fabrico de tecidos

\footnotetext{
("s) Ibid., XII, p. 272.

(ब) Bombelles, pp. 67-8, 78, 87, 160.

(s) P. Agostinho Rebelo da Costa, pp. 18, 276; cf. J. A. Bacellar Chichorro, p. 57 (1795).

(5) J. A. Bacellar Chichorro, p. 57.

( $\left.{ }^{87}\right)$ Segundo Fernando de Sousa, "A memória dos abusos praticados na comarca de Moncorvo de José António de Sá (1790)», Pevista da Faculdade de Letras da Universidade do Porto, Série de História, 1974, vol. IV, pp. 31-2.
} 
de diferentes qualidades, na maior parte, grosseiros, que servem à despesa e usos da gente do campo $\left({ }^{68}\right)$.

Felizmente que essas camponesas ganham um jornal, porque, de outra maneira, não podem casar-se. Ameaça o risco "que os lucros nesses mesmos ofícios não sendo suficientes à sustentação que pede... uma família», se empreguem na prostituição $\left({ }^{69}\right)$. Como antes e noutros paises, por exemplo na Itália do Renascimento e em França, a prostituição era a alternativa para a falta de trabalho $\left({ }^{80}\right)$. Assim seria mais tarde.

Ora as «indústrias populares» haviam perdido importância à medida que a produção nacional fora menosprezada. Discutia-se a qualidade, que baixava diante da concorrência e até porque se fazia maior distinção entre o consumo popular, rural, e o consumo fino, citadino. Como em grande parte eram resultado do trabalho feminino, senão escravo ou de negras, a degradação era comum à produção e às que trabalhavam. Porém as tábricas, por exemplo as da Covilhã, fazem apelo ao trabalho feminino, de escolhedeiras, urdideiras, espinzeiras, cerzideiras, mulheres ou raparigas de menos de 16 anos. Os salários pagos dependem de condições que nada têm que ver com as capacidades femininas $\left({ }^{61}\right)$.

Mulheres dirigem ou criam estabelecimentos, homens vivem do trabalho da esposa. O que conta é o nível social, e em certas circunstâncias, devem sobretudo evitar-se as misturas. E necessário separar gentes que misturam iguais obrigações. No chafariz del-rei em Lisboa, destina-se uma bica a pretos, forros e cativos, "assim mulatos, índios, como os mais cativos que sejam homens", outra aos mouros e aos pretos e mulatos das galés, uma terceira e uma quarta aos homens e mulheres brancos, a quinta a «mulheres pretas, mulatas, índias,

\footnotetext{
$\left({ }^{58}\right)$ Ibid., p. 31.

( $\left.{ }^{50}\right)$ J. A. Bacellar Chichorro, Memória, pp. 54-5.

( ${ }^{60}$ Cf. por exemplo, Richard C. Trexler, «La prostitution florentine au XV $\mathrm{XV}^{\mathrm{e}}$ siècle», Annales, E.S.C., 1981, n. ${ }^{\circ} 6$, pp. 983-1015 e Jacques Rossiaud, «La prostitution dans les villes françaises au $\mathrm{XV}^{\bullet}$ siècle», Communications, 1982 , n..$^{\circ} 35$, p. 80 , bem como Jean Delumeau, Vie économique et social de Rome dans la seconde moitié du XVI' siècle, I, Paris, 1957, p. 416 e segs.

${ }^{\left({ }^{61}\right)}$ Segundo João Manuel Esteves Pereira, $A$ indústria portuguesa. Subsídios para a sua história. Com um ensaio económico-social sobre as corporações e mesteres por Carlos da Fonseca, Lisboa, Guimarães, 1979, pp. 160-1, 163, 165-6, 173-4. Gradualmente empregam-se mulheres e meninos em vez de homens, operários em vez de mestres. Cf. ainda José Gentil da Silva, «A propos de Nice: dépréciation de la monnaie courante et protection des patrimoines (XVI'-XVIII') 》, Annales de la Faculté des Lettres et Sciences Humaines de Nice, 1979 , n. ${ }^{\circ}$ 37, em particular, p. 48.
} 


\section{O Marquês de Pombal}

forras e cativas», enfim a última, da banda de Alfama, às mulheres e moças brancas. Multas pesadas indo até 2.000 réis acompanhadas de 10 dias de cadeia sem remissão, açoites para negros cativos e mouros, ameaçavam os desordeiros. Ao fim e ao cabo, a cor da pele serve de primeiro critério, depois se verá. Assim se contentam os que não apreciam as misturas embora a solução pareça não poder evitar inteiramente confusões, encontros e empurrões ${ }^{62}$ ).

Claro que não aparece aí, nem noutras ocasiões, algo que determine uma forma estrita de divisão do trabalho segundo o sexo; só varia a bica a que todos, brancos ou pretos, machos ou fêmeas, levam o cântaro à fonte. Ademais, acontece até entre gente dessa que se pretende alçada de nível pelo ofício, que uma mulher conserve a loja do defunto, quando enviúva (mesmo se passou a segundas núpcias com pessoa que não é da mesma ocupação). Chega-se a ver que negócio de importância e de responsabilidade, qual seja o abastecimento de neve à cidade e à corte, se confie a uma mulher, Catharina Ricart ${ }^{\left({ }^{63}\right)}$. Mas também são mulheres que dirigem em grande parte a vida familiar, negociam as alianças e transmitem os patrimónios. $\mathrm{O}$ cavaleiro de Oliveira pode escrever, doutamente como é seu hábito, que "não está interdito às damas o papel de embaixador" ( $\left.{ }^{64}\right)$.

As mulheres participam fortemente na producão e em aspectos essenciais: abastecimento, produção agrícola, preparacão das matérias-primas para as manufacturas. Parecem deixar outras actividades, embora necessariamente se deva reconhecer a sua presença um pouco por toda a parte. com os homens no chafariz, na loja, nas fábricas, nas ruas, nos salões em que se intriga ou se decide. Mas porque $o$ país tem e deve ter vergonha da sua produção, vai tê-la também das suas mulheres.

\section{A condição feminina degradada}

A condição feminina degrada-se como a da população e em particular dos trabalhadores. As influências exteriores, civilizadoras no século XVI, e ainda as modas, as pressões políticas que as favorecem, nos séculos XVIII e XIX, encon-

${ }^{(22}$ Cf. J. M. Esteves Pereira, pp. 173-4 e por exemplo, Cav. ${ }^{\circ}$ Oliveira, Recreação periódica, II, p. 184.

$\left({ }^{(3)}\right)$ E. F. Oliveira, Elementos, XV, pp. 460, XVII, 4, 136, 138, 460.

(") Recreação periódica, I, p. 208. 


\section{A situação feminina}

tram a resistência dos portugueses e até da corte. Mas impuseram-se violentamente com sólidas cumplicidades dos interesses económicos e sociais. $\mathbf{O}$ que se sabia das mulheres esclarece-nos sobre o país.

Um facto indica uma perspectiva. No século XVI, as parteiras devem ser habilitadas pelo físico-mor ou pelo cirurgião e pela câmara, no que respeita à sua vida e costumes. De resto, havia muheres capacitadas para praticar a medicina $\left({ }^{65}\right)$. Aqui como lá fora, tira-se gradualmente às mulheres a assistência às parturientes. Ridicularizam-se as parteiras de quem se diz no princípio do século XIX que são "simples mezinheiras». Estranha-se de ver as parturientes no meio de uma legião de fêmeas acocoradas como macacos. Perfumes violentos embora talvez úteis criam um ambiente irrespirável. A criança desaparece debaixo dos estofos de ouro que contrastam com os cabelos sujos e o casacão velho da parteira $\left({ }^{66}\right)$. $\mathrm{Na}$ verdade tal degradação da prática feminina acompanha a da medicina, o que se pode dizer desta é bem mais terrível.

A obstetrícia cria-se lentamente e o que sempre se tentara, mostrar que a mulher «ser à parte, que gesta, pare, amamenta, depois menstrua», tudo características a que se dá enfim um sinal de inferioridade, provarse agora. A malacia é por assim dizer normal e, segundo um dos melhores médicos de Lisboa, o espanhol Monravà e Roca, exige uma atitude benévola, de apoio afectuoso. Se ainda dominam os aspectos desagradáveis do comportamento feminino, que tanto apoquentavam D. Francisco Manuel de Melo e os outros tratadistas, descobre-se enfim essa necessidade de afeição que tanto terá faltado, explicando, provavelmente por sua falta, a agressividade do homem ocidental e em particular dos conquistadores portugueses e espanhóis ( ${ }^{67}$ ).

Para dizer tudo, na verdade "a mulher é uma carga muito pesada que mais se deve desviar e fugir dela do que procurá-la», como se diz na Alemanha, na Inglaterra e em França, repetindo-o as folhas bem pensantes de Lisboa $\left({ }^{68}\right)$. Pesada e difícil de suportar; voltando-se sempre à argumentação de que D. Francisco Manuel de Melo fora arauto, talvez malgré lui, aponta-se que se é feia ou bela, pobre ou rica, estúpida ou

${ }^{\left({ }^{85}\right)}$ Cf. M. F. de Mira, História da medicina..., pp. 88, 99.

${ }^{\left({ }^{6}\right)}$ Bombelles, pp. 34, 105.

${ }^{\left({ }^{87}\right)}$ A. F. de Mira, pp. 203, 209 e segs., 224-5, 234, 285, 287, 313

( $\left.{ }^{88}\right)$ O Anónimo, 1752 , I, n. ${ }^{\circ} 9$, p. 254 da edição citada. Tudo isto, eriçado de confusôes e contradições está na base da propaganda anti-hispânica, cf. Sverker Arnoldson, La leyenda negra. Estúdios sobre sus orígenes. Göteborg, 1960. 
inteligente, traz dificuldades ou pelo menos aborrecimentos. Faz-se a apologia da mediocridade que se pretenderá bem portuguesa e não o é. $\mathbf{O}$ "feito feminino» reside na exigência essen. cial que faz a mulher e a que se responde como se pode, hélas!

Denunciam-se maquillages e pinturas. No século XVI, os homens espanhóis lavavam-se demasiado, na opinião dos alemães, dos polacos e até dos italianos, perfumavam-se, arranjavam-se, numa palavra cuidavam da sua pessoa, como apreciavam os bons leitos e as doces mulheres. Perderam depois pouco a pouco, à força de reprovações, esse acervo de maus hábitos de que se acusam agora as mulheres, imitando os estrangeiros, mas como se fosse uma novidade. São elas que "se escondem debaixo do branco e do vermelho,... não tendo aparentemente de dia mais que vinte anos, se acham à noite ter quarenta e cinquenta». E agora um escândalo dizer das mulheres que "têm as suas escanhoadoras e muitas são as que cada dia se barbeiam e natibus et pudendis». Como, se não têm barba na cara? $\left({ }^{60}\right)$

A elas também se critica a beatice e o que acarretava de desmandos. O exemplo vinha do alto. Faziarse publicar «o mapa... das igrejas que [a rainha e a corte] determinam visitar quinta-feira de Endoenças, a pé...». Isto, é verdade, "para que se não lance pela manhã nada nas ruas por onde há de passar». Acontece até os cidadãos responderem mal às exortações para acompanhar as procissões, iluminar as ruas e festejar os desposórios de príncipes, embora essas manifestações fossem para as meninas uma das raras oportunidades de sair de casa. Assaz contraditoriamente, a rainha D. Maria falará da dificuldade que encontra para tirar ao povo tais manias. Talvez confundisse com o que ouvira dizer no tempo do Marquês. Tinham desaparecido as carpideiras que no princípio do século "ainda estavão de moda em Lisboa» $\left({ }^{70}\right)$.

Se não há carpideiras, há lixo e são as mulheres que lhe dão vazão $\left.{ }^{71}\right)$; nisso se empregam as pretas, omnipresentes na cidade. São elas que representam a mais humilde falange feminina, praticamente ignorada. Mas não são só elas desprezadas. Até nos seus amores, como os soberanos, e em cópia conforme, fidalgotes e intelectuais estrangeirados envilecem a mulher, da cigana à moda, passam à judia "caça perigosa»,

("9) O Anónimo, ed. citada, 1754, III, 2, p. 408. Cf. Cav. ${ }^{\circ}$ Oliveira, Recreação periódica, II, p. 224.

$\left({ }^{70}\right)$ E. F. Oliveira, Elementos, XI, p. 263, nota, 265-6; XII, pp. 53, 55, 145; XV, p. 8. Cav. Oliveira, Recreação periódica, I, p. 127. Cf. Bombelles, pp. 100, 103, 253.

$\left.{ }^{71}\right)$ Bombelles, pp. 33, 81. 


\section{A situação feminina}

tomam «em hora de arrufo» aquela que se lhes não dá. Os casamentos porém ajudam as finanças de cada um. Segue-se melhor a protecção dada às irmãs, às sobrinhas e às filhas necessitadas, que os patrimónios, os títulos e os cargos transmitidos pelas mulheres, desde sempre e em particular durante a expansão. E que, obcecados pelos modelos estrangeiros dominantes, intelectuais, historiadores e economistas dividiram a realidade nacional entre o que era quase bom, como lá fora, ๔. o demais, tradicionalista, retrógrado, como tinham dito alemães e italianos e repetiam ingleses.

Ora se se diz facilmente que "a magnificência acompanha a sujidade e a miséria», se esta vai surgindo do surto capitalista, os equilíbrios ancestrais perduram. As modas femininas chegam de França e já então chocam os seus mais ferventes adeptos pela rapidez com que variam levando a resultados ridículos $\left({ }^{72}\right)$. Andam ainda marginadas e levará tempo para que se discuta bom senso e bom gosto. $O$ país inteiro vive uma multiplicidade de particularismos criados pelos modos desiguais senão opostos de enriquecimento e de afirmação de poderes económicos que escapam ao Estado. $\mathrm{O}$ isolamento das aldeias, dos rurais, não é só falta de estradas, também intervêm essas oposições. As mulheres, trabalhadeiras, intelectuais, cidadãs, vivem a sua vida. Disse-se já e repetiu-se que as meninas não participam das recepções; com a criadagem espreitam de trás da porta $\left({ }^{73}\right)$. Vivendo à parte, têm as suas próprias compensações, risíveis, perigosas.

Como o mesmo D. Francisco Manuel de Melo apontara, as mulheres divertem-se comprando biscates, por comprar: pano de linho, cassas e fio em peças, a colarejas que "se metem pelas casas sem as chamarem». "O género feminino, como mais apetitoso para não comprar aquilo de que se necessita, com tão pronta persuasão se facilita para as ditas compras desnecessárias, o que não faria se faltassem estas ocasiões, fundamento com que... são proibidos semelhantes tratos». Como se escrevera no século XVII, «são sem número as desenvolturas que cometem as mulheres solteiras e casadas, nas ocasiōes que se lhes oferecem no interior das suas casas, por onde geralmente se introduzem... bufarinheiros a oferecer a venda de vários dixes e bagatelas que trazem, pretexto este que a elas lhes serve para encobrir sem corar o seu incauto
(22) Ibid., pp. 32, 203.
(') Ibid., pp. 100, 253. 
procedimento, e a eles para as ditas desenvolturas e furtos que cometem nas entradas das casas» $\left({ }^{74}\right)$.

Dir-se-ia que os tendeiros exageram, se não houvesse a quase total coincidência com o que se tinha já afirmado. Ecoando ainda precedentes acusações, diz-se do luxo, que arruína as famílias. Porém as rendas são de má qualidade, o resto inutilidades, e nisso tratam agora também estrangeiros. A resposta é fácil. Se não houvesse senão bufarinheiros e colarejas! Com efeito há "médicos, cirurgiões, mestres de diferentes artes e oficiais de toda a casta de ofícios que se demoram dias inteiros e parte da noite nas casas, acarretadores e criadas de servir». Quanto às dívidas, mais as provocam tendeiros que vendem fiado $\left({ }^{75}\right)$.

Seguindo uma ideia que de fora viera no século XVI e se afirmara no século XVII, ideia que coincide com o horror da mulher, escreve-se "que se tem o matrimónio feito ambicioso e traz consigo para casa com o luxo e a despesa, e com as despesas a que muitas vezes não podem chegar as forças, o perigo de que nascem ordinariamente mais discórdias do que filhos». Quem diz luxo, diz galantarias ou, pelo menos, as boas maneiras, o exercício que defende Vernei. A educação é particularmente necessária às mulheres. Assim se pratica ainda a segregação, esquecendo o que se dizia, que os defeitos são mútuos. O embaixador De Bombelles e a sua senhora passeiam para fortalecer a saúde com um exercício agradável, dando um bom exemplo, porque as senhoras portuguesas não andavam a pé, nem a cavalo $\left.{ }^{78}\right)$. Os estrangeirados não vão tão longe e quando traduzem textos ingleses para civilizar os conterrâneos, excluem das suas adaptações morigeradoras as passagens que se referem à educação feminina. As mães deviam, isso sim, emprezar preceptores que ensinem os rudimentos do cristianismo, em vez de gastar dinheiro com mestres de dança $\left({ }^{77}\right)$.

Seja como for, as portuguesas dançam molemente as contradanças inglesas "um tanto parvas», sabem melhor o minuete de certo mais lascivo e que, na verdade, faz suar menos, felizmente. Di-lo De Bombelles que reconhece terem talvez as portuguesas os cabelos mais espessos e longos de todas as mulheres europeias, admirando-se que num país tão influen-

(“) E. F. Oliveira, Elementos, XIII, pp. 275-8.

(is) Ibid., p. 280 e segs.

("8) O Anónimo, ed. citada, $1752, \mathrm{I}$, n. ${ }^{\circ} 9$, p. 254 e p. 268 , nota 31. Vernei, Verdadeiro método de estudar, carta 16, apêndice. Bombelles, pp. 39, 109, 126.

(") O Anónimo, ed. citada, pp. 106 e 268, nota 31. 


\section{A situação feminina}

ciado pelo judaísmo, as pessoas se lavem tão raramente. (Sejamos justos reconhecendo que o embaixador acha que as inglesas da feitoria cheiram a bacalhau $\left({ }^{78}\right)$. Eram inimigas dele).

A verdade era que as portuguesas que tinham saído do país não tinham ganho muito com isso; mais do que as das outras, as suas risotas faziam lembrar patos bravos $\left({ }^{79}\right)$. Não admira, a propósito das mulheres e da crítica que se lhes faz. em particular a propósito das portuguesas cuja submissão é incompleta, vai-se de uma contradição à outra. Porque são ou devem ser inferiores e isso é difícil de estabelecer, recusa-se-lhes a capacidade de discutir com os homens. Mestre Robert Ricard estudou o caso da freira mexicana sor Juana Inés de la Cruz que quisera impugnar Vieira e o soubera fazer $\left({ }^{80}\right)$. Também em Lisboa se escreveu a seu respeito e o autor assinou com um nome feminino, como o fizera o bispo de Puebla. Seria demasiado que um homem corrigisse uma pobre freira, embora isso fosse necessário. Os antagonismos tornam-se gradualmente mais duros. Este século XVIII, mole mas cruel, gera a violência que reinará no século XIX, até às grandes emigrações.

Os estudantes vão para Coimbra "com armas ofensivas e defensivạs, com pólvora e balas e cães de fila». Por isso o Marquês agira brutalmente contra os cabeças do motim que em 1757 ofendeu o reitor. Alguns tinham ido parar à India; outros estiveram presos no Limoeiro ou em Coimbra. Acabou-se perdoando-lhes as faltas $\left({ }^{81}\right)$. Passada a época do Marquês, os antagonismos que vinham de antes e que ele exacerbara, fortaleceram-se. Os fidalgos jovens sofriam desta situação que impedia namoriscos. Algumas famílias, as casas de Obidos, de Castelo Melhor, de Vila Nova, de Penalva, são indicadas como dum "puritanismo aparente». Por isso as mulheres viam como uma grande liberdade que um homem lhes desse a mão para as ajudar a descer uma escada. 0 reinado de D. Maria, rotineiro, entorpecido pelo carácter doce ou fraco da soberana, leva a administração e o resto do país ao

(i8) Bombelles, pp. 108 e 313-4.

$\left({ }^{70}\right)$ Ibid., p. 252.

$\left.{ }^{80}\right)$ Robert Ricard, "António Vieira et sor Juana Inés de la Cruz», Etudes sur l'histoire morale et religieuse du Portugal, Paris, Centro Cultural Português, 1970, pp. 293-319.

( ${ }^{81}$ ) Ribeiro Sanches, Método para estudar a medicina (1753), citado por Ricardo Jorge, Amato Lusitano. Comentos à sua vida, obra e época, Lisboa, s. d., p. 53, nota 2, e Mário Alberto Nunes Costa, Documentos para a história da Universidade de Coimbra (1750-1772), I, Universidade de Coimbra, 1959, pp. 241, 242, 244, 245, 246, 248, 274. 
caos que prepara futuras explosões. Serão mais tardias do que no pa:s do embaixador; então as mulheres contribuirão e participarão activamente nas lutas e nas intrigas $\left(^{\mathbf{8 2}}\right)$.

Tudo isso passa como anedota. Portanto, se nos últimos anos do século XVIII, o hospital Real de São José em Lisboa, recebe mais homens (536) que mulheres (215), o número de loucos é o mesmo para os dois sexos (60) o que proporcionalmente representa o dobro para elas $\left({ }^{83}\right)$. Fraqueza congénita do género? Foi o que se pretendeu entre o Renascimento e o século XX.

Retomavarse o velho adágio, que lembrara D. Francisco Manuel de Melo, que a mulher é sábia se arruma um, até dois baús de roupa. Tinha-se mudado? Estaria a mulher já «em outro tom?" Tratava-se agora da "acusação das meninas", como lá fora $\left({ }^{84}\right)$. A protecção delas preocupara sempre os pais e as instituições. As câmaras e as misericórdias, os particulares também, gastavam o que tinham e o que não tinham, com as crianças pobres, órfãs, abandonadas. Tratava-se de uma constante da história de Portugal que vira sempre sair do país os seus filhos jovens e os vira voltar, se voltam, tardiamente, para casar e depressa deixarem mulheres viúvas, em plena idade fértil. Passado o século XVIII, as famílias operárias não teriam melhor sorte. As mulheres voltavam ao mercado do trabalho em condições verdadeiramente inferiores, opondo-se aos homens que não podiam deixar de reagir à pressão que faziam sobre os salários.

\section{Conclusão}

Trata-se menos de concluir que de tentar conjugar estas observações com a história das ideias e das práticas. Ultimamente, a História aprendeu a utilizar novos documentos que fizeram entrar nas nossas explicações as populações e as famílias, mas a mulher ficou ainda isolada na sua especificidade. Estuda-se a fecundidade e a mortalidade diferencial; os comportamentos em relação ao casamento e à procriação têm sem dúvida o maior interesse. Porém, no trabalho e na produção,

(“) Bombelles, pp. 136, 162-3, 174, 253.

(8.) lbid., pp. 290-1.

(*4) Então berra-se no teatro, «eu sempre ouvi dizer a minha avó...» José Daniel Rodrigues da Costa, A menina discreta da fábrica r: $v a$ (1789), editado em José Daniel Rodrigues da Costa, 6 entremeses de cordel, Lisboa, Estampa-Seara Nova, 1973, pp. 199-242, por Luís Miguel Cintra e Jorge Silva Melo. Cf. Francisco José de Almeida, Tratado da educação das meninas (1791). 
na vida cultural e política, a mulher intervém tanto pelo menos como o homem. Ademais, ela contribui para a definição por este da sua própria opinião e das suas escolhas. Esta intervenção não pode ser dada por subentendida.

Ora a Europa moderna elaborou um equilíbrio instável, precário, exigindo que nem todas as potencialidades humanas se desenvolvam. A escolha fez-se sacrificando virtualidades femininas e mais do que isso, todas as que foram atribuídas às mulheres, com exclusão pois de parte do espírito e da sensibilidade do Homem, portanto de virtualidades femininas mas também de masculinas. Sociedades, economias, sistemas familiares e políticos numa palavra, em que a sensibilidade conta pouco e a brutalidade é considerada conquistadora, aboliram os sentimentos e substituiram-nos por um sentimentalismo de cantochão confundido com sinceridade e lhaneza. Quem pode o mais, pode o menos. Porém, a resistência continuou da parte principalmente das mulheres, exactamente por falta do essencial, da sua satisfação fisiológica.

Condenou-se o género feminino ao isolamento, à reserva, corolário da sua inferioridade. A verdade é que a Igreja não jogou inteiramente esse jogo, e menos ainda o jogaram os frades e os curas. A inferioridade apregoada da mulher acompanhou-se de repressão contra esses homens e contra quem era afinal tão inferiorizado como ela. Tal inferioridade afirmada desde o século XIV e mais fortemente no século XV, foi no século XVI estabelecida com o apoio da experiência clássica em que se havia seleccionado convenientemente o que devia servir a tão grande projecto.

Portugal, como a Espanha, fica fiel às tradições e aos costumes que honram a mulher, apesar do culto marial e da falta de homens que o deixavam cedo. Fora talvez mais sensível à influência clássica que o seria depois à do mundo burguês, embora, por exemplo, a mulher acabe por tomar o apelido do marido, como se fazia lá fora. No século XVIII, a portuguesa continua a não entender inteiramente o estatuto que lhe querem impor. No século XIX ainda, choca os estrangei. ros, pela sua ousadia e a sua graça. Isto parece ainda vincar mais a sua inferioridade e a miséria material e moral do país que não se verga aos costumes e aos padrões do consumo estrangeiros.

Porém os filhos dos portugueses não eram meninos; depressa corriam para fora do reino (como os espanhóis), antes para a Africa e a Asia, depois para as Américas, no século XVIII para o Brasil (como no século XIX). Muitos calcorreavam «terríveis e tenebrosos caminhos» sem ter vivido afeição. 


\section{O Marquês de Pombal}

Desencaminhado numa civilização importada, cuja sensibilidade se peralvilhara, por falha precisamente de sinceridade, o país, saído da pressão a que o submetera a administração pombalina, bocejava de tédio, clamava por sangue nas corridas de toiros, por falta de autos de fé. Esperava as guerras intestinas em que também as mulheres gritam e agem, já não dançam nos salões, dançam e cantam nas ruas e nas azinhagas. Já elas participaram no tumulto que ergueu as ruas do Porto contra a Companhia em 1757; quatro foram executadas, uma quinta escapou por estar prenhe. Outras 33 foram condenadas a penas diversas $\left.{ }^{85}\right)$. $O$ exílio sempre fora familiar. Nove mulheres foram então degredadas para os reinos de Angola e Benguela, depois de açoutadas (só 8 homens), uma para Angola, após confiscação dos bens, mas sem açoutes ( 3 homens), cinco para fora da comarca (26 homens). Nenhuma para os Estados da India (4 homens).

Entre a ilha dos Amores e a experiência do mundo ultramarino, a história dos portugueses, deles e delas, deve muito a tais situações. $O$ "feito feminino" abre-nos perspectivas novas, mais do que dá matéria a reivindicações sexistas. Foi nesse sentido que quisemos chamar a atenção dos historiadores das ideias para ele.

('5) P.• Agostinho Rebelo da Costa, Descrição... do Porto, p. 353 e segs. 